\title{
CASIMIRO DE BRITO: \\ O “RIGOR E A CLARIDADE ENIGMÁTICA DO PENSAMENTO”
}

\author{
Claudio Alexandre Barros Teixeira ${ }^{1}$
}

\begin{abstract}
RESUMO: $O$ artigo aborda o trabalho desenvolvido por Casimiro de Brito para a divulgação da poesia japonesa em Portugal por meio da tradução, da reflexão crítica e do próprio exercício poético na forma do haicai, adaptada às possibilidades da língua portuguesa. Entre as questões teóricas apresentadas no presente texto está a discussão sobre a atividade tradutória compreendida como recepção criativa, que estabelece uma tensão entre a língua de partida e a de chegada, entre diferentes repertórios culturais e tempos históricos, transformando o texto original em um novo artefato semântico.
\end{abstract}

PALAVRAS-CHAVE: Haicai, tanka, ideograma, recepção, tradução.

\section{CASIMIRO DE BRITO: THE ACCURACY AND ENIGMATIC CLARITY OF THINKING}

ABSTRACT: The article discusses the work of Casimiro de Brito for the dissemination of Japanese poetry in Portugal through translation, critical reflection and own poetic exercise in the form of haiku, adapted to the possibilities of the Portuguese language. Among the theoretical issues presented in this text is the discussion of translational activity understood as creative reception establishing a tension between the source language and the arrival between different cultural repertoires and historical times, turning the original text in a new semantic artifact.

KEYWORDS: Haiku, tanka, ideogram, reception, translation.

Casimiro de Brito realiza instigante trabalho tradutório, crítico e criativo de divulgação da poesia japonesa em Portugal, organizando antologias de haicaístas japoneses, como Poemas orientais (1962), Poesia japonesa (1995) e Apenas um ruído (1996), que reúnem composições de Bashô, Issa, Buson, Shiki e outros autores do repertório nipônico, além de organizar um dossiê sobre o haicai japonês do século XX para a revista brasileira Poesia sempre ${ }^{2}$ e de publicar haicais de sua própria autoria nos livros $\grave{A}$ sombra de Bashô (2001), A boca da fonte (2012) e Eros mínimo (2014). O poeta, que participou de um dos movimentos de renovação das letras portuguesas, o Poesia 61, também realizou importante mapeamento dos autores portugueses que se dedicaram ao haicai, o que resultou na antologia Uma rã que salta - Homenagem a Bashô (1995). No presente artigo, discutiremos alguns tópicos relativos ao trabalho tradutório, crítico e poético de Casimiro de Brito, inseridos no contexto da recepção criativa da poesia japonesa em Portugal. Para termos uma compreensão do significado do trabalho de divulgação do haicai

\footnotetext{
1 Claudio Alexandre de Barros Teixeira realizou o mestrado e o doutorado em Literatura Portuguesa pela Universidade de São Paulo, defendendo tese sobre o tema "A recepção da poesia japonesa em Portugal". Atualmente, realiza pós-doutorado em Teoria da Literatura pela Universidade Federal de Minas Gerais. Como poeta, publicou diversos livros com o pseudônimo de Claudio Daniel, entre eles Figuras metálicas (São Paulo: Perspectiva, 2004).

2 Poesia Sempre n. 17, ano 10, Rio de Janeiro, 2002.
} 


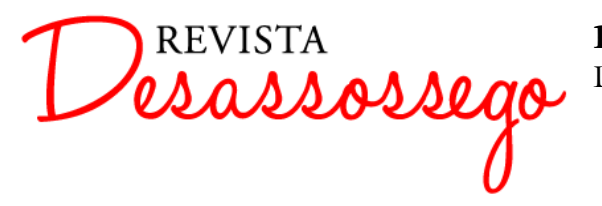

DESASSOSSEGO 16 | DEZ/2016 | ISSN 2175-3180

DOI: http://dx.doi.org/10.11606/issn.2175-3180.v8i16p90-104

por Casimiro de Brito no cenário literário de Portugal é importante ressaltar que a poesia portuguesa, desde as primeiras décadas do século XX até os grupos que se articularam em torno de revistas como Presença, Árvore e Prisma não assimilou qualquer influência da poesia japonesa, apesar das traduções pioneiras realizadas por Wenceslau de Moraes, na década de 1920, publicadas no livro Relance da alma japonesa (1926). Os poetas ligados à revista Orpheu Fernando Pessoa, Mário de Sá-Carneiro, Almada Negreiros - dialogaram com a poesia clássica grega e romana, com a lírica elisabetana, com a poesia simbolista francesa, Walt Whitman, o futurismo europeu, mas em nenhum momento com a arte concentrada de Bashô e seus discípulos. A ausência de diálogo criativo com a poesia japonesa nas letras portuguesas nesse longo período é um caso excêntrico, uma vez que os leitores europeus e norte-americanos já entraram em contato com o haicai e a cultura japonesa muito tempo antes. Conforme escreve Octavio Paz:

$\mathrm{Na}$ história das paixões do Ocidente pelas outras civilizações há dois momentos de fascínio diante do Japão, se esquecermos o engonement dos jesuítas no século XVII e o dos filósofos no século XVIII: um se inicia em França em fins do século passado e, após fecundar diversos pintores extraordinários, culmina com o Imagism dos poetas angloamericanos; outro começa nos Estados Unidos alguns anos depois da Segunda Guerra Mundial e ainda não terminou. O primeiro período foi, antes de tudo, estético; o encontro entre a sensibilidade ocidental e a arte japonesa produziu várias obras notáveis, tanto na esfera da pintura - e o exemplo maior é o impressionismo - como na da linguagem: Pound, Yeats, Claudel, Éluard. No segundo período a tonalidade tem sido menos estética e mais espiritual ou moral; isto é, não só nos apaixonam as formas artísticas japonesas como também as correntes religiosas, filosóficas ou intelectuais de que são expressão, em particular o budismo. (PAZ, 1996, p. 171)

Uma das principais referências desse diálogo "entre a sensibilidade ocidental e a arte japonesa" a que se refere Octavio Paz é a publicação, em 1902, do livro Bashô and the japanese poetical epigram, de autoria do estudioso britânico Basil Chamberlain. Quatro anos depois, o orientalista francês Paul-Louis Couchoud publica na revista Les lettres dois importantes ensaios: Les haikai e Les épigrammes lyriques du Japon, esse último acompanhado de cerca de cem haicais traduzidos, possivelmente a partir do inglês. Conforme diz Paulo Franchetti, o segundo ensaio de Couchoud foi republicado no volume Sages et poetes d'Asie, em 1916, e o livro "correu o mundo, precedido de um prefácio de Anatole France, tornando-se uma das principais referências sobre o assunto, para os leitores de formação francesa" (FRANCHETTI, 2012, p. 200). Nesse mesmo ano, Julien Vocance (nome literário de Joseph Seguin) publica uma coletânea de haicais intitulada Cent visions de guerre, e em 1921 "sistematiza as suas ideias sobre o haicai e o seu papel de exemplo de uma nova arte poética. Trata-se de Art poétique, que saiu na revista La connaissance" (idem, 201). Apesar da contribuição dos estudos de autores franceses e 


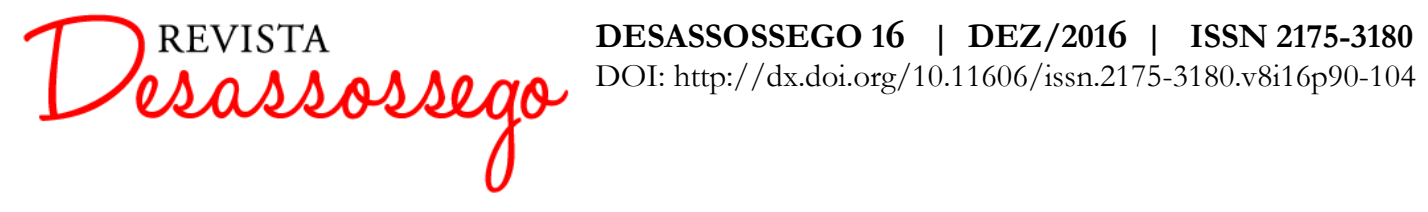

britânicos sobre o haicai e a cultura japonesa, foi graças ao norte-americano Ezra Pound que “a poesia japonesa passou a ser uma referência realmente importante no Ocidente" (idem, 44), escreve Paulo Franchetti. O autor dos Cantos "fará da reflexão sobre a poesia chinesa e japonesa um dos pontos centrais da sua influente concepção de poesia e literatura" (idem). Na obra teórica e ensaística de Ezra Pound, "a poesia do Extremo Oriente não vai ser nem uma preocupação lateral de um grande poeta (esse era o caso de Camilo Pessanha), nem uma referência importante de um poeta sem nenhuma influência duradoura (como se dá com Amy Lowell, por exemplo)" (idem). Pound descobriu o haicai e as peças de teatro Nô a partir de seu interesse pela escrita e poesia chinesas - ele foi o editor do livro Os caracteres da escrita chinesa como instrumento para a poesia, de Ernst Fenollosa, que leu pela primeira vez em 1913, quando recebeu os originais que lhe foram entregues pela viúva do sinólogo. Nesta obra singular, "os caracteres chineses eram entendidos radicalmente como ideogramas, isto é, sinais que mantêm uma relação muito próxima com o objeto, ação ou propriedade que representam” (idem, 41). Pound irá valorizar, sobretudo, a justaposição de imagens no ideograma, "em que a relação entre as partes é de natureza metafórica" (idem, 42), recurso que utilizou na concepção estrutural de seu poema longo Os cantos (ou Cantares ${ }^{3}$ ), que escreveu entre 1917 e 1949, no qual inseriu também personagens e episódios reais e lendários da cultura chinesa e japonesa, mesclados a citações enciclopédicas da literatura, da história e da mitologia de diferentes culturas ocidentais, constituindo, segundo Haroldo de Campos, um "imenso ideograma da cosmovisão poundiana, irredutível a um desenvolvimento tradicional, de progressão linear, sob o esquema princípio-meio-fim" (CAMPOS, 1977, p. 58). Ezra Pound foi o "inventor da poesia japonesa" para o nosso tempo, escreve Paulo Franchetti (parodiando a célebre frase de T. S. Eliot), porque "a desvinculou de uma vez para sempre das leituras que a reduziam a um exotismo sentimental e afetado, sem nenhum interesse para a poesia do Ocidente" (idem, 47), ao mesmo tempo que investiu na assimilação de elementos da estética chinesa e japonesa em seu próprio trabalho poético (e recordemos aqui o poema Numa estação de metrô, um quase haicai em que não faltam o signo da estação do ano e o flash de uma cena cotidiana, assim traduzido por Augusto de Campos: "A visão destas faces dentre a turba: / Pétalas num ramo úmido, escuro", POUND, 1983, p. 93). Ao lado de Pound, outra referência que precisa ser

\footnotetext{
${ }^{3}$ No livro $A$ arte no horizonte do provável, Haroldo de Campos afirma: "a própria armadura ideogrâmica dos Cantos, numa escala macroscópica, guarda analogia com a estrutura básica de superposição de elementos do haicai. Em 1914, visualizando o que seria um longo poema imagista ou vorticista, escreveu Pound: 'Perguntam-me, frequentemente, se poderia haver um poema longo imagista ou vorticista. Os japoneses, que produziram o haicai, produziram também as peças Nô. No melhor Nô, a peça inteira... é reunida em torno de uma imagem... Nada tenho contra um longo poema vorticista"' (CAMPOS, 1977, p. 57).
} 


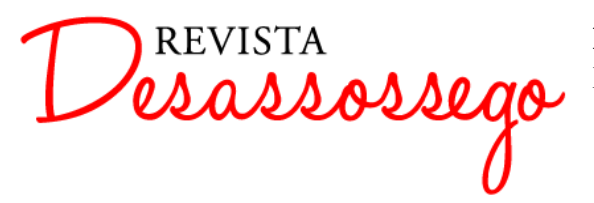

DESASSOSSEGO 16 | DEZ/2016 | ISSN 2175-3180

DOI: http://dx.doi.org/10.11606/issn.2175-3180.v8i16p90-104

citada é a do escritor norte-americano Reginald Horace Blyth, autor da importante antologia Haiku, obra em quatro volumes com traduções de poemas de Bashô, Issa, Buson outros poetas menos conhecidos no Ocidente. Segundo Paulo Franchetti, "suas traduções e comentários aos haicai, aos senryu $u^{4}$ e aos textos zen são de valor inestimável para todo estudioso da literatura japonesa no Ocidente" (idem). Ele conhecia profundamente "não só a literatura japonesa como ainda a chinesa e a coreana, e sua familiaridade com os poetas de língua inglesa era também invejável” (idem). Blyth tornou-se um ícone da cultura pop nas décadas de 1950 e 1960, contribuindo para a divulgação da estética e da espiritualidade japonesa, ao lado de autores como D. T. Suzuki e Allan Watts, que foram essenciais para a formação de poetas como Allen Ginsberg, Gary Snyder e Jack Kerouac. Todo esse rico diálogo entre a cultura japonesa e o Ocidente, no entanto, só frutificaria no cenário poético português no final da década de 1950, quando Casimiro de Brito (nascido em 1938), em viagem de estudos na Inglaterra, entrou em contato com o haicai. Em depoimento publicado na revista Zunái, o poeta português afirma:

Em 1958, numa espécie de exílio político (para me libertar do eminente recrutamento para a Guerra Colonial), fui para Londres e freqüentei o Westfield College. Era um curso de verão, organizado pela BBC, e coube-me ficar instalado nos aposentos de um professor de Poesia Oriental. Foi um deslumbramento - estar dentro de uma pequena biblioteca de poesia que eu desconhecia. E os livros de haiku deslumbraram-me. Na Universidade havia alunos de mais de 50 países e, entre eles, uma japonesa. Aproximei-me dela, contei-lhe quem era e ao que vinha: que ela me ajudasse a traduzir alguns daqueles poetas já que algumas das traduções inglesas não me agradavam. Disse-me que sim, e foram semanas, meses de trabalho delicado e quase abençoado; foi uma relação amorosa iluminada pela poesia. Quando regressei a Portugal a minha poesia transformou-se noutro mundo porque não só se desenvolvia na tradução dos famosos mestres japoneses como eu próprio comecei a escrever de outra maneira. (in Zunái, Revista de Poesia e Debates n. XXVI, março de 2013)

Fascinado pela condensação poética do haicai, sua economia verbal, sutileza e ironia, o poeta português desenvolve atividades de estudo e tradução da poesia japonesa, além de escrever, ele próprio, composições na forma do terceto e de organizar antologias com trabalhos de outros autores portugueses que se dedicaram às formas do tanka e do haicai, de modo ocasional ou sistemático (Uma rã que salta - Homenagem a Bashô. Porto: Limiar, 1995). Seu trabalho no campo da tradução (realizado em parceria com Natsuishi Ban'Ya, professor de francês na Universidade de Tóquio), acompanhado de estudos críticos, está reunido em três publicações: Poemas orientais, pequeno volume editado em 1962, na cidade de Faro, o caderno

\footnotetext{
${ }^{4}$ O senryu (川柳, literalmente, "salgueiro do rio") é um gênero poético japonês semelhante ao haicai, dividido em três versos, somando 17 sílabas, mas sem o signo da estação do ano (o kigo) e de caráter irônico ou cínico, não raro aproximando-se do humor negro.
} 


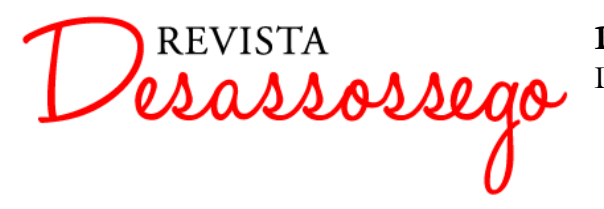

DESASSOSSEGO 16 | DEZ/2016 | ISSN 2175-3180

DOI: http://dx.doi.org/10.11606/issn.2175-3180.v8i16p90-104

Poesia japonesa, separata da revista de poesia Limiar n. 5, editada no Porto, que saiu em 1995, e Apenas um ruído, coletânea publicada em 1996 na revista Nova Renascença n. 60/63, editada na mesma cidade. As traduções de Casimiro de Brito diferenciam-se daquelas realizadas por Wenceslau de Moraes na década de 1920 por não serem apenas registros literais, não raro com adições explicativas ou decorativas ausentes nos textos originais, o que aliás também verificamos nas traduções que Jorge de Sena realizou de Bashô e publicadas em sua monumental antologia Poesia de 26 séculos, das quais citamos, como amostragem, sua versão para o poema da rã: “Quebrando o silêncio / do charco antigo a rã salta / n'água - ressoar fundo" (in SENA, 1972, p. 11). Casimiro de Brito, ao contrário de seus ilustres predecessores, busca conservar não apenas a informação semântica mas também a simplicidade e a coloquialidade do haicai tradicional, e sobretudo o estilo conciso, por vezes seco e abrupto dos textos japoneses, como nesta curiosa composição: "Narciso e biombo: / iluminam-se, branco / no branco, um ao outro" (Bashô, 1644-1694, In BRITO, 1995, p. 13), que podemos comparar com versão similar feita por Paulo Leminski: "narciso / biombo / um ao outro ilumina / branco no branco" (BASHÔ, 1983, p. 59), e ainda com a versão de Jorge de Sena: "Um branco narciso / E um branco biombo se reflectem / na sala quieta" (In SENA, 1972, p. 12). A abstração deste poema, que já foi comparado com a pintura de um artista europeu de vanguarda como o suprematista soviético Casimir Maliévitch, contrasta com a delicadeza de outra composição, quase uma fotografia do cotidiano: "Mulher sem filhos - / como ela é terna / com as bonecas!” (Ransetsu, 1654-1707, In BRITO, 1995, p. 13). A metáfora comparece de maneira inusitada nesta peça: "Mulheres no arrozal - / tudo nelas é sujo / menos o seu canto" (Raizan, 1654-1716, In BRITO, 1995, p. 13), e ainda neste poema de refinada construção imagética: “O vento, no outono, / toma a forma do capim, / tão espesso!” (Kigin, 1624-1704, In BRITO, 1995, p. 12). A participação do eu poético, raridade em uma escrita poética tão impessoal, está registrada nesta composição, associada a outra metáfora: "A cobrir os milênios / da minha ausência / o véu duma cascata" (Natsuishi Ban’Ya, 1955, In BRITO, 1995, p. 17). Casimiro de Brito obtém resultados poéticos consistentes em português, evitando a afetação e o exotismo, tipo rice powder poetry, males citados por Haroldo de Campos em sua crítica às traduções de poesia oriental filtradas por um simbolismo finissecular. Ao mesmo tempo que evita os clichês associados a uma ideia romântica de "Oriente", Casimiro de Brito não intentou uma recriação radical da estrutura do ideograma, aquilo que Haroldo de Campos chamava de "metáfora visual" e que é inseparável tanto da escrita como do pensamento japonês. A dimensão plástica dessa micropoética altamente condensada permite-lhe "um extremo 


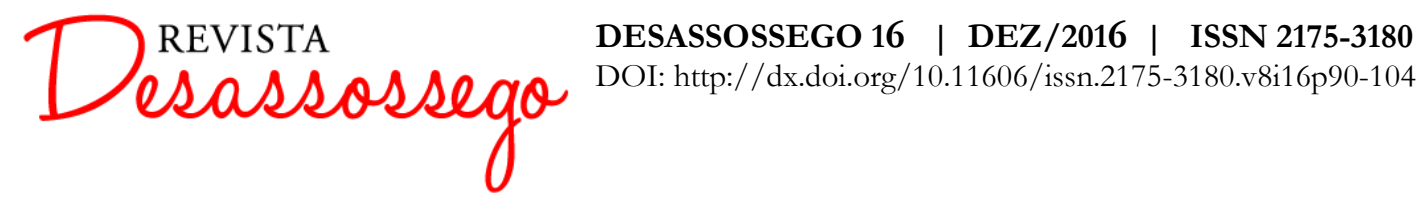

refinamento de percepção, um grande poder de síntese imaginativa, em consonância, aliás, com o espírito poético japonês" (CAMPOS, 1977, p. 65), afirma o poeta e ensaísta brasileiro, citando como exemplo a palavra yumê ("sonho" em japonês), "expressa pelos desenhos abreviados, superpostos, de vegetação crescendo + rede de pesca + cobertura + sol-pôr" (idem, 64). É impossível deixar de pensar "nos estímulos que este simples vocábulo, a partir de seu casulo gráfico, oferece à imaginação poética. É ele, por si só, um verdadeiro diorama de estratos metafóricos" (idem). "No pensamento por imagens do poeta japonês", prossegue o autor brasileiro, "o haicai funciona como uma espécie de objetiva portátil, apta a captar a realidade circundante e o mundo interior, e a convertê-los em matéria visível” (idem, 65). Casimiro de Brito desconsidera a dimensão visual da escrita e os jogos polissêmicos do kakekotoba $a^{5}$ em sua recriação da poesia japonesa para o nosso idioma, mas mantém a alta precisão, a dicção enxuta e substantiva do verso japonês, sua simplicidade e espontaneidade, características de todas as artes tradicionais influenciadas pelo zen. A naturalidade da própria caligrafia japonesa, que incorpora o traçado rápido, o borrão e os contornos assimétricos e imprecisos, dificilmente poderia ser recriada em um método de tradução que valoriza o controle do acaso e o rigoroso cálculo prévio dos efeitos, como é o caso da transcriação haroldiana. Neste sentido, podemos considerar válida a observação de Paulo Franchetti, para quem esse método leva a um afastamento "do contexto de produção e recepção, bem como da função social de um dado texto em uma dada sociedade", privilegiando as "correspondências sintáticas, semânticas e sonoras" (FRANCHETTI, 2012, p. 49). "Quando o poema a ser traduzido pertence a um universo de referências próximo a essa visão de literatura, o método tem resultados excelentes, como se pode ver na tradução que Haroldo de Campos fez do Un coup de dés, de Mallarmé" (idem), prossegue Paulo Franchetti, fazendo a ressalva que "na leitura do haicai, no entanto, que provém de um outro universo de referências, esses pressupostos têm mais efeitos nocivos do que positivos" (idem, 50), citando como exemplo a tradução que Haroldo de Campos fez do famoso poema da rã, de Bashô:

\footnotetext{
${ }^{5}$ A montagem, inerente ao princípio da escrita ideográfica, também comparece, no plano semântico, num recurso peculiar da poesia japonesa chamado kakekotoba, ou "palavra pendurada", que Haroldo de Campos define como "um recurso de compressão semântica e ambiguidade poética, algo como a 'palavra-valise' de Lewis Carrol e Joyce. Assim, matsubara significa 'pinheiral' (matsu, pinheiro; bara, campo), mas, ao mesmo tempo, matsu é um verbo, com a acepção de esperar”. (CAMPOS, 1993, p. 20)
} 


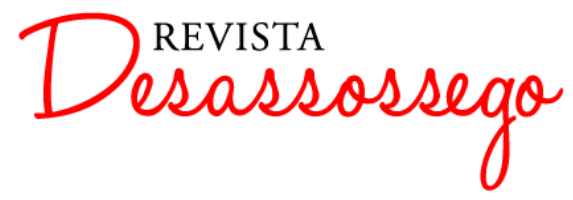

o velho tanque

rã salt’

tomba

rumor de água

(CAMPOS, 1977, p. 62)

$\mathrm{Na}$ opinião de Paulo Franchetti, “em face da poética de Bashô, que sempre demonstrou aversão à mera exibição técnica em haicai (...), a utilização de uma 'palavra-valise' à James Joyce parece completamente inadequada" (idem, 51). O autor justifica seu severo parecer argumentando que "o bokkeu de Bashô, célebre por inaugurar a maneira despojada e não simbólica de uma escola que se dizia acessível a crianças e incultos, converte-se em um precioso micropoema ostensivamente trabalhado com agudez̧a e engenho" (idem, 51) (observemos aqui o uso de palavras extraídas do vocabulário barroco, com intenção crítica; os grifos são meus). O parecer de Franchetti leva em consideração o contexto histórico e cultural em que a poesia japonesa foi produzida e também sua legibilidade na época atual, ou seja, ele reconhece a relevância do receptor e do sentido, e é neste ponto que podemos fazer uma breve discussão sobre a poética da tradução. Conforme diz Walter Benjamin no ensaio $A$ tarefa do tradutor, "levar em consideração o receptor de uma obra de arte ou de uma forma artística" em hipótese alguma "revela-se fecundo para o seu conhecimento" (BENJAMIN, 2011, p. 101), uma vez que "o próprio conceito de um receptor 'ideal' é nefasto em quaisquer indagações de caráter estético, porque estas devem pressupor unicamente a existência e a essência do homem em geral" (idem). Numa obra poética, continua o autor, "o que lhe é essencial não é comunicável, não é enunciado" (idem, 102), motivo pelo qual a tradução literal seria a “transmissão inexata de um conteúdo inessencial" (idem). Aquilo que realmente importa num poema, para Benjamin, é “o inapreensível, o misterioso" (idem), cabendo ao tradutor a tarefa de encontrar, em seu próprio idioma, um eco "capaz de reproduzir (...) a ressonância de uma obra estrangeira" (idem, 112), tal como fez Hoelderlin em suas versões das tragédias de Sófocles, ou ainda Voss com as traduções de Homero, reconhecendo porém que "toda tradução é apenas um modo algo provisório de lidar com a estranheza das línguas", permanecendo "vedada aos homens (...) uma solução não-temporal e provisória para essa estranheza, uma solução instantânea e definitiva" (idem, 110). O autor alemão conclui o seu ensaio fazendo uma longa citação de Rudolf Pannwitz, para quem "o erro fundamental de quem traduz é conservar o estado fortuito da sua própria língua, ao invés de deixar-se abalar violentamente pela língua estrangeira" (idem, 118). O autor considera que, "sobretudo quando 


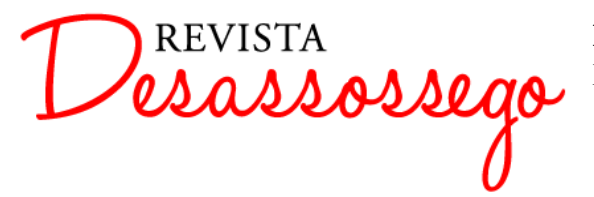

DESASSOSSEGO 16 | DEZ/2016 | ISSN 2175-3180

DOI: http://dx.doi.org/10.11606/issn.2175-3180.v8i16p90-104

traduz de uma língua muito distante, ele deve remontar aos elementos últimos da língua mesma, onde palavra, imagem e som se tornam um só. Ele tem de ampliar e aprofundar sua língua por meio da língua estrangeira” (idem). As teses defendidas por Benjamin e Pannwitz encontram ressonância nas formulações teóricas de Haroldo de Campos, para quem a tradução é "recriação, ou criação paralela, autônoma, porém recíproca" (CAMPOS, 2004, p. 35). "Quanto mais inçado de dificuldades esse texto, mais recriável”, prossegue o autor brasileiro. Numa tradução dessa natureza, "não se traduz apenas o significado, traduz-se o próprio signo, ou seja, sua fisicalidade, sua materialidade mesma (propriedades sonoras, de imagética visual, enfim, tudo aquilo que forma, segundo Charles Morris, a icoinicidade do signo estético" (idem). O significado, ou "parâmetro semântico", conclui, "será apenas e tão-somente a baliza demarcatória do lugar da empresa recriadora. Está-se pois no avesso da chamada tradução literal” (idem). A tradução de poesia, de acordo com esse pensamento, seria, antes de tudo, "uma vivência interior do mundo e da técnica do traduzido. Como que se desmonta e se remonta a máquina da criação, aquela fragílima beleza aparentemente intangível que nos oferece o produto acabado numa língua estranha" (idem, 43). A estratégia de transcriação adotada por Haroldo de Campos obteve resultados extraordinários, do ponto de vista da construção formal, mas a ressalva apresentada por Paulo Franchetti permanece válida; como resolver o impasse entre a recriação e o espírito de despojamento da filosofia zen-budista? Temos aqui um caso para a liberdade de escolha do tradutor, que pode adotar o método que encontrar correspondência com a sua visão particular sobre a poesia e a literatura, uma vez que nenhuma tradução será perfeitamente exata ou inexata, em especial quando se trata do haicai, com todas as suas camadas de significação, tanto semânticas quanto históricas e culturais, muitas delas intraduzíveis. A operação tradutória, tal como a entendemos, não busca uma verdade unívoca, mas a relação estética e de pensamento entre o tradutor e o texto traduzido. Conforme Karlheinz Stierle, "nenhum texto diz apenas aquilo que desejava dizer. Cada texto sofre a coerção inevitável de produzir uma comunicação suplementar e não prevista" (in LIMA, 2011, p. 131), o que atribui à recepção um evidente caráter lúdico, e nos faz pensar nas concepções de Wolfgang Iser, para quem “os autores jogam com os leitores e o texto é o campo do jogo. O próprio texto é um ato intencional pelo qual um autor se refere e intervém em um mundo existente, mas, conquanto o ato seja intencional, visa a algo que ainda não é acessível à consciência” (idem, 107). Isto ocorre porque "o texto é composto por um mundo que ainda há de ser identificado e que é esboçado de modo a incitar o leitor a imaginá-lo e, por fim, interpretá-lo" (idem). "Essa dupla operação de imaginar e interpretar", prossegue, "faz 


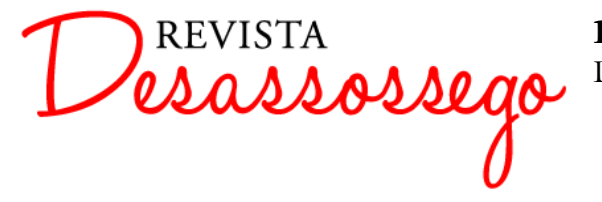

DESASSOSSEGO 16 | DEZ/2016 | ISSN 2175-3180

DOI: http://dx.doi.org/10.11606/issn.2175-3180.v8i16p90-104

com que o leitor se empenhe na tarefa de vislumbrar as muitas formas possíveis do mundo identificável, de modo que, inevitavelmente, o mundo repetido no texto começa a sofrer modificações" (idem). A mudança do campo referencial na recepção, conforme Stierle, pode ser sintetizada nesta afirmação: “a relação do texto com a realidade não é uma simples função de uma realidade a ser retratada, mas sim de uma poética da ficção, que pode ser ora mais, ora menos relacionada com a realidade e com a experiência coletiva da realidade” (idem, 131).

O próprio Casimiro de Brito, no prefácio aos Poemas orientais, diz: “A poesia é intraduzível, e a minha tentativa de verter para o português, de fažer poesia a partir dos haicais japoneses, sem lhes roubar a magia, o clímax oriental é, reconheço-o, demasiado arriscada" (BRITO, 1962, p. 10). Em consequência, "penitencio-me dizendo que foi uma tentação, e considero estes poemas breves um pouco como poesia minha” (idem). Quando Casimiro de Brito fala em "fazer poesia a partir dos haicais japoneses" ele apresenta uma proposta-desafio similar à de Pound, analogia que ganha força quando pensamos que o poeta português, assim como o norte-americano, exercitou-se na criação conforme o estilo de uma época (operação ao mesmo tempo crítica e criativa), nos haicais de sua autoria. Para termos uma ideia do rigor com que Casimiro de Brito trabalhou em suas traduções, vamos comparar algumas peças que comparecem nas antologias Poemas orientais (1962) e Poesia japonesa (1995):

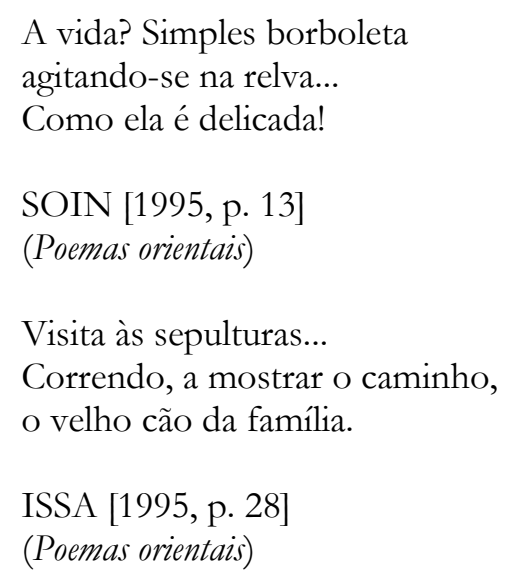

A vida? Borboleta agitando-se na relva Tão delicada!

SOIN [1962, p. 12]

(Poesia japonesa)

Visita ao cemitério.

O velho cão de família ensina o caminho

ISSA [1962, p. 16]

(Poesia japonesa)

Nas traduções incluídas no volume Poemas orientais (1962), notamos versos mais longos, de sintaxe regular, próxima ao ritmo da prosa. Já nas composições compiladas em Poesia japonesa (1995) há maior concisão, cortes sintáticos e ritmo mais seco, que reforçam o poder de impacto da imagem poética. Os elementos temáticos e formais desse conjunto de traduções serão incorporados e transformados na poesia do próprio Casimiro de Brito, que realiza uma notável mescla do imaginário tradicional japonês com uma sensibilidade moderna temperada pelas vanguardas européias, que reivindicavam a síntese, a concisão, a ruptura com a lógica 


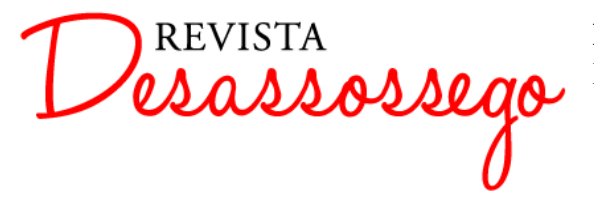

DESASSOSSEGO 16 | DEZ/2016 | ISSN 2175-3180

DOI: http://dx.doi.org/10.11606/issn.2175-3180.v8i16p90-104

sintático-discursiva, a visualidade e o pensamento analógico (lembremos que Casimiro de Brito integrou um dos movimentos de renovação da poesia portuguesa, o chamado Poesia 61, aliás contemporâneo da PO-EX, liderado por Ana Hatherly e E. M. de Melo e Castro. Ao contrário dos experimentalistas, porém, a Poesia 61 não investiu na poesia visual, concentrando-se na pesquisa criativa do poema-texto, que se desenvolve na dimensão temporal, não na espacial).

Todos esses elementos construtivos estão presentes no ambicioso projeto que Casimiro de Brito denominou LIVRO DOS HAIKU, obra em progresso desenvolvida desde 1958 que será constituída de 14 livros, sendo que apenas dois foram publicados até a presente data: 1) $A$ sombra de Bashô (renga que intercala haicais traduzidos do poeta japonês com outros de autoria do próprio Casimiro de Brito); 2) renga com Ban’Ya; 3) (Elementos, estações); 4) Eros minimo; 5) Devastação; 6) Da comoção; 7) Através do ar (editado no Japão, em quatro línguas, em parceria com Ban'Ya); 8) Amando, escrevendo; 9) Para além; 10) Outras músicas; 11) Desprendimento; 12) No amor tudo se move; 13 e 14) antologias de haikus antigos e contemporâneos. O primeiro livro deste ciclo, $\grave{A}$ sombra de Bashô, uma elegante publicação em formato vertical e textura roxa na capa e contracapa, de $14,5 \mathrm{~cm}$ por $35 \mathrm{~cm}$, é um conjunto de 110 poemas alinhados na forma de renga, gênero poético japonês em que dois ou mais poetas participam, intercalando os versos. Conforme escreve Shuichi Kato, "cada um faz uma estrofe relacionada exclusivamente à última estrofe composta, sem nenhuma necessidade de considerar as estrofes anteriores." (KATO, 2011, p. 94). "O fluir do renga não é planejado", afirma o autor japonês, "ele segue conforme as ideias que surgem no momento, ora mudando-se o tema, ora o cenário, ora a emotividade (idem)." Nessa forma de fazer poético regida pela mobilidade, casualidade e surpresa, sem uma unidade ou foco de interesse, o encanto reside no "encontro inesperado", na "engenhosidade" e na "retórica" de cada estrofe apresentada (idem). Em À sombra de Bashô há um elemento insólito adicional, que é o diálogo involuntário de um poeta-samurai japonês do século XVII com um autor português do século XX, que responde aos haicais de Bashô, traduzidos diretamente do idioma original e apresentados em itálico, com outros haicais, concebidos de maneira paródica (no sentido original da palavra, que em grego significa "canto dialogado"). Assim, o conhecido poema de Bashô "No velho tanque - / uma rã salta, mergulha - / ruído na água" (In BRITO, 2001, p. 7) é seguido por esta composição de Casimiro de Brito: "Na página branca / na branca voz - outra rã / salta. Silêncio” (In BRITO, 2001, p. 7), que introduz, sub-repticiamente, uma terceira VOz na renga, a do simbolista francês Stéphane Mallarmé, representado por algumas de suas obsessões - o silêncio, a página em branco e o acaso. Outro poema de Bashô, "O mar escurece / ouço grasnar os patos / vagamente 


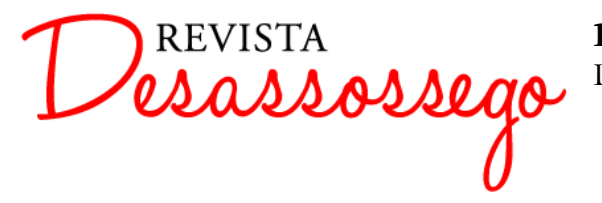

DESASSOSSEGO 16 | DEZ/2016 | ISSN 2175-3180

DOI: http://dx.doi.org/10.11606/issn.2175-3180.v8i16p90-104

brancos" (In BRITO, 2001, p. 11) recebe a seguinte resposta criativa de Casimiro de Brito: "Nuvem deitada / Os olhos espreitam o peixe / que vai saltar" (In BRITO, 2001, p. 11), em que a metáfora e o close cinematográfico de uma imagem inusitada respondem às sinestesias do poema anterior. Este haicai também foi traduzido por Jorge de Sena, na referida antologia Poesia de 26 séculos, do seguinte modo: "No mar que escurece / grita voando o pato: / é o que se vê: suave branco" (apud SENA, 1972, p. 12), versão convencional que contrasta com a força elíptica e paratática da recriação de Paulo Leminski: “o mar escurece / a voz das gaivotas / quase branca” (LEMINSKI, 1983, p. 36). O diálogo poético estabelecido por Casimiro de Brito com Matsuo Bashô não hesita em subverter o sentido dos poemas com os quais conversa, nem guarda pudores em relação a princípios do haicai tradicional, injetando o sensualismo (ausente na lírica do poeta samurai), metáforas complexas, citações metalinguísticas, a presença ostensiva do eu lírico e referências urbanas que denunciam o poeta como um cidadão da modernidade, em contraste com o mundo místico, simples e rural de um Japão que não mais existe (tornou-se literatura). Alguns exemplos da riqueza imagética das composições de Casimiro de Brito:

42

Aproximam-se as patas

invisíveis do sol -

de sombras calçadas. (In BRITO, 2001, p. 13)

58

O sol adormece

no seu lençol de nuvens

- insônia vermelha. (In BRITO, 2001, p. 17)

Podemos recordar, lendo estes poemas, de alguns haicais de Bashô que colocam em primeiro plano a imagem rara, como esta peça traduzida por Paulo Leminski: "chuva de primavera / a água escorre do teto / pelo ninho de vespas” (in LEMINSKI, 1983, p. 51), ou ainda: "relampagueia / através das trevas / a garça ecoa" (idem, 50). Bashô, samurai sem mestre (浪人; 浪, ronin) que tornou-se monge zen-budista, tematiza o amor universal, a compaixão por todos os seres vivos, de todos os gêneros e condições sociais, até mesmo pelas plantas e os insetos ("sob o mesmo teto / dormem rameiras, a lua / e também o trevo" (In BRITO, 2001, p. 23), na tradução de Casimiro de Brito), mas nada fala sobre o amor erótico ${ }^{6}$

\footnotetext{
${ }^{6}$ A temática erótico-amorosa será mais frequente na poesia japonesa a partir da Restauração Meiji, destacando-se a produção de Yosano Akiko (1878-1942).
} 


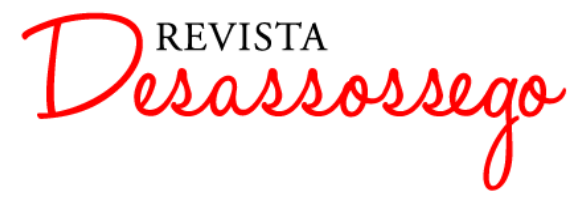

DESASSOSSEGO 16 | DEZ/2016 | ISSN 2175-3180

DOI: http://dx.doi.org/10.11606/issn.2175-3180.v8i16p90-104

(embora fosse contemporâneo dos Livros de primavera, romances pornográficos em voga na época, e dos rengas satíricos produzidos por comerciantes e soldados); já o poeta português elege esse tema como um dos pontos centrais de seu labor criativo, como podemos ler nesta composição de extrema sutileza e delicadeza: "Cabelos que vou pentear / a noite inteira. O vestido / junto à lareira” (In BRITO, 2001, p. 15). Em outros momentos da renga, Casimiro de Brito inclui haicais de caráter filosófico, como se fossem aforismos, como acontece no último poema do volume: "Talvez a morte não / exista. Talvez seja apenas / viagem, flutuação" (In BRITO, 2001, p. 26). A afinidade entre o haicai e o aforismo foi percebida por Maria João Cantinho, que, na resenha do livro mais recente de Casimiro de Brito, A boca da fonte (2012), escreve: "A estética do baiku tem, ainda, vários pontos de afinidade com o aforismo, pela mesma retórica, pelo mesmo sentido de economia e de rigor poético", motivo pelo qual “tenha entrado na literatura ocidental pela estética do fragmento, tão cara aos poetas alemães românticos, tendo como cultor máximo do gênero o poeta Novalis"” (CANTINHO, 2013). "A estética do haiku ou do fragmento", prossegue a autora, "recusa a ideia de um acabamento ou de uma definição da obra e esta vai-se fazendo à medida que se escreve cada poema, definindo-se precisamente pela ausência da sua definição" (idem). Desse modo, a poesia concentrada colhe, em cada verso, “a imperfeição e o segredo, o inesperado" (idem). Os vetores conceituais apresentados por Maria João Cantinho em seu texto são instigantes pontos de partida para uma discussão do conjunto de cem haicais que Casimiro de Brito compilou em seu livro $A$ boca da fonte. A série não tem unidade temática, nem é dividida em focos de interesse; os poemas são numerados e alinhados em grupos de dois, quatro ou cinco por página, sem um critério de organização claramente identificável. Os haicais de Casimiro de Brito raramente têm rimas e a métrica não é sempre exata, embora esteja próxima das medidas japonesas, de 5-7-5 sílabas. O autor prescinde do signo da estação do ano, o kigo, mas investe na concisão, na economia sintática e nos cortes elípticos, e por vezes dialoga com imagens e recursos da poesia japonesa, como acontece nesta peça: "Vagueiam pela casa / o homem, a mosca e o ar -- / ninguém descansa" (BRITO, 2012, p. 14), onde a enumeração de personagens humanos e não-humanos em um mesmo cenário e situação recorda os princípios da interdependência e da compaixão budista por todos os seres vivos, temas de numerosos haicais de Bashô, como este poema, traduzido por Kimi Takenaka e Alberto Marsicano: “em profundo silêncio / o menino, a cotovia / o branco crisântemo" (BASHÔ, 1997, p. 10). A reflexão filosófica é a tonalidade que predomina na maioria das composições de $A$ boca na fonte,

${ }^{7}$ Casimiro de Brito: A boca na fonte, resenha publicado no n. XXVII da revista Zunái (março / 2013) 


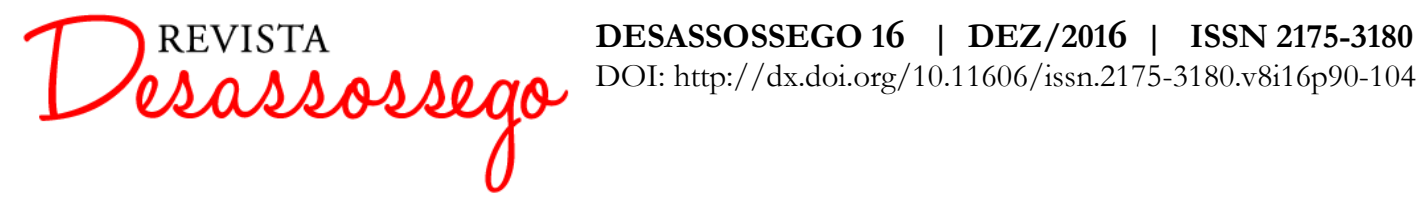

em outro ponto de contato com os aforismos de autores alemães como Nietzsche e Novalis; essa "busca do primordial, do ato de beber diretamente da fonte", escreve Maria João Cantinho, está contida já no título da obra, que alude à imersão "no sentido da natureza e simultaneamente da linguagem” (idem). A inflexão filosofante, sob o signo da água, aparece já na peça de abertura do volume: "Não separes a água / da sua espuma - / a vida é só uma" (BRITO, 2010, p. 7), que parece responder aos axiomas de Tales de Mileto e Heráclito de Éfeso, bem como à tradicional imagem budista que representa o mundo fenomênico como algo temporário, mutável, sem realidade permanente, tal como a espuma nas águas de um rio. Casimiro de Brito, divergindo da ótica budista, parece dizer o oposto: que essência e aparência, substância e acidente formam uma unidade ("a vida é só uma"). O elemento líquido aparece em diversas composições do livro, em geral com o mesmo viés existencial ou filosofante, por vezes com timbre melancólico: "Silêncio. Ouçam / a vida - água correndo / cada vez mais triste" (idem, 16), que recorda a imagem da clepsidra, na poesia de Camilo Pessanha; "Em cada pedra / um rio que não cessa / de louvar as margens" (idem, 26); "Lágrimas que são / cascata pura. Outras vezes / avalanche mortal” (idem, 28). A água, símbolo da mobilidade, fluidez, mutação e brevidade dos fenômenos, é um dos motivos-condutores de $A$ boca na fonte, ao lado de outros elementos da natureza, como as montanhas, as vacas, os bambus, os gatos e os figos, entre muitos outros. Conforme Maria João Cantinho,

Se os elementos e a força da terra e da natureza perpassam a sua poética, sob as mais variadas formas, desde a ínfima gota de chuva ou grão de areia até ao enigmático silêncio das constelações, também o onírico deflagra, a todo o instante, para nos recordar a brevidade da vida e do instante: "Viagem nocturna -/ regresso à origem do sonho/donde nunca saí. (CANTINHO, 2013)

Morte, sonho, infância, destino e linguagem são outros temas que aparecem nesta coletânea de haicais, que compõem uma espécie de diário íntimo do poeta, um registro de lembranças (reais ou inventadas), terrores, desejos, obsessões. As peças mais originais do livro, no entanto, são as sete que comparecem nas páginas finais, sob o título $C f$. Lautréamont. Traçar um paralelo entre a poesia japonesa, com todo o seu lastro zen-budista, e a prosa cruel de Isidore Ducasse parece um paradoxo, ou mesmo impossibilidade, mas Casimiro de Brito consegue sair-se bem na dificultosa empresa, fazendo uma releitura intertextual focada na imagética surrealizante, como na peça de abertura da série: "A terra não passa / de um imenso cu celeste / fremindo, cantando". Claro, este já não é um haicai stricto sensu, mas um terceto que estabelece o diálogo possível entre elementos na estética japonesa - concisão, fala popular, imagens raras, relação Céu-Terra, o imprevisto - e o repertório linguístico e temático dos 


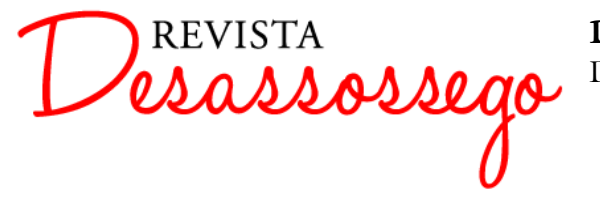

DESASSOSSEGO 16 | DEZ/2016 | ISSN 2175-3180

DOI: http://dx.doi.org/10.11606/issn.2175-3180.v8i16p90-104

Cantos de Maldoror, como a pederastia (indicada, de maneira metonímica, na palavra $c u$ ), a imaginação fantástica ou bizarra, a atribuição de características humanas a formas inanimadas (este "cu celeste / fremindo, cantando", que recorda ainda o William Burroughs de O bomem que ensinou o seu cu a falar). Em outro poema da série, Casimiro de Brito escreve: "Mãos vegetais / raízes de árvores invisíveis / trepando nas veias". Neste poema, ainda mais estranho que o anterior, as aliterações em $v$ e $s$ podem ser comparadas aos trocadilhos e jogos verbais da poesia japonesa, como o kakekotoba, e as "árvores invisíveis", numa leitura um pouco forçada, podem remeter ao signo da estação do ano, o kigo; porém, a fúria semântica e metafórica dessas linhas está bem mais próxima do simbolismo e do surrealismo europeus, movimentos aos quais Lautréamont, em geral, é associado. "Mãos vegetais" é uma bela imagem, mas talvez soasse, a um poeta como Bashô, mera exibição de virtuosismo; “árvores invisíveis" é igualmente construção mental, diferente do registro da observação direta dos fenômenos. A organização estrutural do poema em duas partes, separadas por um travessão, aproxima-se da lógica compositiva de muitos haicais japoneses (p. ex., "Cerejas do anoitecer - / Hoje também / já é outrora”, de Issa, na tradução de Paulo Franchetti, 1990, p. 99), mas o efeito causado é totalmente diverso: no haicai, mesmo a sinestesia, a metáfora e o paradoxo remetem a uma paisagem observada, ou à ação de algum elemento da natureza, sem nenhuma brecha para relações intertextuais cultas, obscuridade ou devaneios do poeta. Ao colocar em primeiro plano a sua fantasmagoria pessoal, parodiando as fantasias de Lautréamont, Casimiro de Brito, guiado "pelo rigor e pela claridade enigmática do pensamento" (CANTINHO, 2013), caminha para além da mera adaptação de uma forma poética oriental para o nosso idioma, obtendo um resultado poético denso, com originalidade formal e temática.

\section{REFERÊNCIAS BIBLIOGRÁFICAS}

BASHÔ, Matsuo. Trilha estreita ao confim. Trad.: Alberto Marsicano. São Paulo: Iluminuras, 1997.

BENJAMIN, Walter. Escritos sobre mito e linguagem. São Paulo: Duas Cidades / Editora 34, 2011.

BRITO, Casimiro de. Poemas orientais. Faro, 1962.

Poesia japonesa. Separata da Revista de poesia Limiar n. 5. Porto, 1995.

À sombra de Bashô. Faro: colecção do Grito Claro, 2001.

Uma rã que salta - Homenagem a Bashô. Porto: ed. Limiar, 1995. 


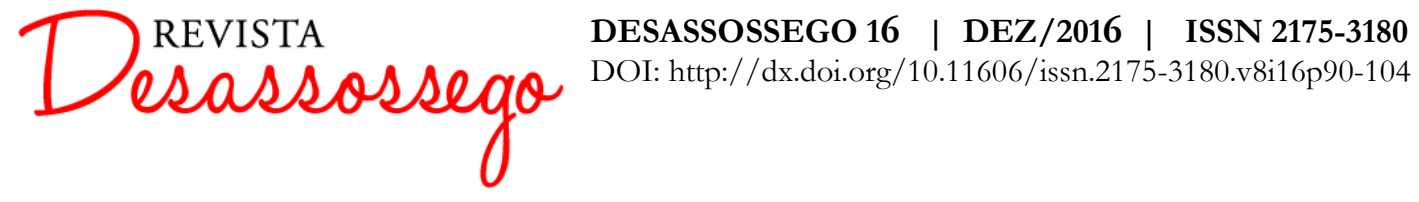

. A boca da fonte. Póvoa de Santa Iria: Lua de Marfim - Editora Unip. Lda., 2012.

CANTINHO, Maria João. In Zunái, Revista de Poesia e Debates n. XXVI. São Paulo, março de 2013.

FRANCHETTI, Paulo, DOI, Elza Taeko e DANTAS, Luiz. Haikai. Antologia e história. 1a. edição: Campinas: Editora da Universidade Estadual de Campinas, 1990. 4ª edição: Campinas: Editora da Universidade Estadual de Campinas, 2012.

KATO, Shuichi. Tempo e espaço na cultura japonesa. São Paulo: Estação Liberdade, 2012.

LEMINSKI, Paulo. Bashô, A lágrima do peixe. São Paulo: ed. Brasiliense, 1983.

LIMA, Luiz Costa. A literatura e o leitor. São Paulo: Paz e Terra, 2011.

Teoria da literatura em suas fontes. Rio de Janeiro: Francisco Alves, 1983. V. II.

PAZ, Octavio. Versiones y diversiones. Tabasco: Editorial Joaquín Mortiz, 1974.

PAZ, Octavio. Signos em rotação. São Paulo: Perspectiva, 1996.

SENA, Jorge de. Poesia de 26 séculos. Porto: Editorial Inova Limitada, 1971, 2 vols. 